worldwide and to help apply technology and management practices to give maximum economic and social returns from national road investments.

Founded following the Second World War, over the years the IRF has led major global road infrastructure developments, including achieving $1,000 \mathrm{~km}$ of new roads in Mexico in the 1950s, and promoting the Pan-American Highway linking North and South America. It publishes World Road Statistics, as well as road research studies, including a 140-country inventory of road and transport research in co-operation with the US Bureau of Public Roads.

Headquarters: 2 chemin de Blandonnet, CH-1214 Vernier,

Geneva, Switzerland.

Website: http://www.irfnet.org

Chairman: Kiran K. Kapila (India).

\section{International Seabed Authority (ISA)}

The ISA is an autonomous international organization established under the UN Convention on the Law of the Sea (UNCLOS) of 1982 and the 1994 Agreement relating to the implementation of Part XI of the UNCLOS. It came into existence on 16 Nov. 1994 and became fully operational in June 1996.

The administrative expenses are met from assessed contributions from its members. Membership numbered 166 in Feb. 2014; the budget for the biennium 2011-12 was US $\$ 13,014,700$.

The UNCLOS covers almost all ocean space and its uses: navigation and overflight, resource exploration and exploitation, conservation and pollution, fishing and shipping. It entitles coastal states and inhabitable islands to proclaim a 12-mile territorial sea, a contiguous zone, a 200 -mile exclusive economic zone and an extended continental shelf (in some cases). Its 320 Articles and nine Annexes constitute a guide for behaviour by states in the world's oceans, defining maritime zones, laying down rules for drawing sea boundaries, assigning legal rights, duties and responsibilities to States, and providing machinery for the settlement of disputes.

Organization. The Assembly, consisting of representatives from all member states, is the supreme organ. The 36-member Council, elected by the Assembly, includes the four largest importers or consumers of seabed minerals, four largest investors in seabed minerals, four major exporters of the same, six developing countries representing special interests and 18 members from all the geographical regions. The Council is the executive organ of the Authority. There are also two subsidiary bodies: the Legal and Technical Commission (currently 25 experts) and the Finance Committee (currently 15 experts). The Secretariat serves all the bodies of the Authority and under the 1994 Agreement is performing functions of the Enterprise (until such time as it starts to operate independently of the Secretariat). The Enterprise is the organ through which the ISA carries out deep seabed activities directly or through joint ventures.

Activities. In July 2000 the ISA adopted the Regulations for Prospecting and Exploration for Polymetallic Nodules in the Area. Pursuant thereto, it signed exploration contracts with eight contractors who have submitted plans of work for deep seabed exploration. These are: Institut Français de Recherche pour l'Exploitation de la Mer (IFREMER) and Association Française pour l'Etude de la Recherche des Nodules (AFERNOD), France; Deep Ocean Resources Development Co. Ltd (DORD), Japan; State Enterprise Yuzhmorgeologiya, Russian Federation; China Ocean Minerals Research and Development Association (COMRA); Interoceanmetal Joint Organization (IOM), a consortium sponsored by Bulgaria, Cuba, Czech Republic, Poland,
Russia and Slovakia; the government of the Republic of Korea; the Republic of India; and the Federal Institute for Geosciences and Natural Resources, Germany.

Between 1998 and 2012 the ISA organized 14 workshops on a range of topics, including: the development of guidelines for the assessment of the possible environmental impacts arising from exploration for polymetallic nodules; a standardized system of data interpretation; and prospects for international collaboration in marine environmental research.

Headquarters: 14-20 Port Royal St., Kingston, Jamaica.

Website: http://www.isa.org.jm

Secretary-General: Nii Allotey Odunton (Ghana).

Publications. Handbook 2012; Selected Decisions and Documents from the Authority's Sessions; various others.

\section{International Telecommunications Satellite Organization (ITSO)}

Founded in 1964 as Intelsat, the organization was the world's first commercial communications satellite operator. Today, with capacity on a fleet of geostationary satellites and expanding terrestrial network assets, Intelsat continues to provide connectivity for telephony, corporate network, broadcast and internet services.

Organization. In 2001 the member states of the organization implemented restructuring by transferring certain assets to Intelsat Ltd, a new commercial company under the supervision of the International Telecommunications Satellite Organization, now known as ITSO. In 2009 Intelsat Ltd moved its corporate headquarters to Luxembourg and became Intelsat S.A. ITSO's mission is to ensure that Intelsat provides public telecommunications services, including voice, data and video, on a global and non-discriminatory basis. The governing body of ITSO is the Assembly of Parties, which normally meets every other year. The Executive Organ is headed by the Director-General and is responsible to the Assembly of Parties. The Director-General supervises and monitors Intelsat's provision of public telecommunications services. There were 149 member countries in Feb. 2014.

Headquarters: 3400 International Drive, NW, Suite 3M-100, Washington, D.C., 20008-3006, USA.

Website: http://www.itso.int

Director-General: José Manuel Toscano (Portugal).

\section{International Trade Union Confederation (ITUC)}

Origin. Founded in Nov. 2006, the ITUC was formed through a unification process that included the merger of the International Confederation of Free Trade Unions (ICFTU) and the World Confederation of Labour (WCL) with the addition of several national centres that had not been affiliated with either organization. The WCL was established in 1920 as the International Federation of Christian Trade Unions, but went briefly out of existence in 1940 owing to the suppression of affiliated unions by the Nazi and Fascist regimes. It reconstituted in 1945 and became the WCL in 1968. The founding congress of the ICFTU took place in London in Dec. 1949 following the withdrawal of some Western trade unions from the World 